\title{
Perceived Effect of Motivation on the Job Performance of Library Personnel of Universities in Benue State, Nigeria
}

\author{
Margaret Mngusuur Ubagu ${ }^{1}$ and Joseph Ahemba Gbuushi ${ }^{2} *$ \\ ${ }^{1 \& 2}$ University Library and Information Services, Benue State University, Makurdi, Nigeria. \\ *Correspondence: josephgbuushi@gmail.com
}

\begin{abstract}
The study was conducted on the perceived effect of motivation on the job performance of library personnel of universities in Benue State. Two objectives were formulated to find out the perceived effect of training and salary payment on job performance of library personnel of universities in Benue State. Two research questions and two hypotheses were also formulated in line with the formulated objectives. The survey research design was adopted. The study population was 223 library personnel from the Federal University of Agriculture, Makurdi, Benue State University, Makurdi and University of Mkar, Mkar. The entire population was used for the study hence there was no sample and sampling. A self-structure questionnaire was used for data collection. The questionnaire was subjected to face and content validity. Cronbach alpha was used to test the reliability of the instrument which yielded the value of 0.94. Mean values were used to answer research questions while one-way Analysis of Variance (ANOVA) was used to test hypotheses at 0.5 level of significance. The study found that training and salary payments have a significant difference on job performance of library personnel of universities in Benue State. The study recommended, therefore, that university library personnel should be sent for constant training and retraining; they should also be paid salaries for optimum job performance.
\end{abstract}

Keywords: Motivation, Job performance, University library, Personnel, Salary, Benue state, and Training.

\section{INTRODUCTION}

An organization usually consists of a group of people working together for the achievement of set goals. One of the primary aims of any organization is to accomplish higher productivity. This could effectively be achieved when both human and material resources of such an organization are well managed. Research has shown that variables such as job motivation and satisfaction are connected to improving the degree of the job performance of staff in any organization which in turn controls the level of productivity (Katamba and Abdusalam, 2014).

Motivation is concerned with the aspect of human life that boosts, propels and encourages human beings to change behavior for the attainment of an organization's goals and objectives, thereby achieving higher productivity (Madukoma et al., 2014). According to Kendra (2018), motivation is viewed "as the use of incentives to person from whom the activity is needed or required". Job satisfaction is connected with motivation and consequently, satisfaction leads to better performance. For workers to be effectively directed and to perform better in their roles, personnel motivation must be given proper attention that is staff training and payment of salary as at when due (Rafiei and Davari, 2015). Others are the availability of appropriate working tools, effective communication, good staff policies, and job security among others. This shows that 
workers' motivation is an important component of management. To reap the organization's goals, employees need to execute their duties as desired. Job performance is the discharge of legal duties or functions based on workers' field of specialization.

According to Idiegbeyan-Ose et al. (2019) job performance is regarded as that aspect of the work behavior domain that is connected to the job and the organization's goals. Job performance differs from organizations to organizations. For example, jobs performed in libraries include selection, acquisition, cataloguing and classification of materials, borrowing and returning of library materials to users among others.

Madukoma et al. (2014) decried that research and observation show that most times users of library resources complain of library personnel failure to attend to their information needs properly. This has been attributed to a lack of motivation which as a result, influences their job performance. The poor motivation of employees resulting in poor performance of tasks assigned to them is one of the main problems confronting organizations in Nigeria, the school organization particularly library personnel of Nigerian Universities (Akor, 2010). It is based on this that the study was carried out to find out the perceived effect of motivation on the job performance of library personnel of universities in Benue State.

\section{Statement of the Problem}

Library personnel are the interface between the information resources and the users. Motivating them is therefore very crucial in determining the quality of services they offer to these users. Unfortunately, there is an outcry of poor services rendered by library personnel of Nigerian universities. University libraries in Benue State are not an exception to this unfortunate development as it is observed that most users complained of poor services rendered to them. Could this be as a result of lack of training or delay in payment of salaries? It is against this premise that this study is undertaken to investigate the perceived effect of motivation on the job performance of library personnel of universities in Benue State, so as to fill the research gap in the literature.

\section{Objectives of the Study}

The main objective of the study is to investigate the perceived effect of motivation on the job performance of library personnel of universities in Benue State.

Specifically, the study sought to:

a) Find out the perceived effect of training on the job performance of library personnel of universities in Benue State;

b) Ascertain the perceived effect of salary payment on the job performance of library personnel of universities in Benue State.

\section{Research Questions}

In line with the purposes of the study, the following research questions guided the study:

a) What are the perceived mean ratings of the effects of training on the job performance of library personnel of universities in Benue state?

b) What are the perceived mean ratings of the effects of salary payment on the job performance of library personnel of universities in Benue state?

\section{Statement of Hypotheses}

The following null hypotheses were formulated and tested at 0.5 level of significance.

Ho1: There is no significant difference between the mean ratings of responses of library personnel on perceived effects of training on the job performance of library personnel of universities in Benue State.

Ho2: There is no significant difference between the mean ratings of responses of library personnel on perceived effects of salary payment on the job performance of library personnel of universities in Benue State.

\section{Clarification of Concepts}

Motivation - Motivation is one of the most critical factors that determine organizational performance; be it in the public or the private sector. It plays an 
important role in the success of any organization (Chintallo and Mahadeo, 2013). Tumba and Temboge (2018) ascertains that it is widely recognized that motivation plays a role in keeping an employee performing at his/her best in any task assigned to the employee. Motivated employees help organization survive and are more productive. Library personnel should, therefore, be motivated by giving them training in different areas of their profession. This in effect will help them acquire different skills that will boost their job performance. Madukoma et al. (2014) are in agreement that training motivates library personnel in universities to do their jobs.

Upev et al. (2015) posit that in the discharge of effective library services, staff are to be motivated on the basis of both intrinsic and extrinsic conditions such as promoting, grades approval; prizes and commendations, accurate working environment, and friendly labor management relationship. Motivation and productiveness are tied to human behavior. It is towards this backdrop that Mabaso and Dlamini (2017) describes human assets as the most vital task upon which all results depend and on how well it is executed. Motivation has a totally sturdy have an effect on staff output, this presupposes why Upev et al. (2015) counseled that it should now not be constrained to staff being paid regularly and promptly but in proportion to the volume of services rendered.

Job performance - Job performance refers to the degree of accomplishment of the work activities carried out by the worker towards the achievement of organizational goals. Iqbal et al. (2013) stated that employees will put in their best in performing their jobs if they are motivated. Furthermore, Silva and Borsato (2017) stated that job performance has become one of the significant indicators in managing organizational performance. Moreover, a growing emphasis has been given at the employee's process overall performance as a source of competitive advantage to sell responsiveness in enhancing standard organizational effectiveness. Moreover, Kibichii et al. (2016) contended that training outputs ought to emphasize performance, not just learning, which is the employer's expectations from training.

\section{Training and job performance of university library personnel}

Training is an essential tool for the development of staff and personnel in their field of endeavor. Nyitse (2016) defines training as the process through which experience is deliberately offered to trainees to enable them to absorb some new perspective, understanding, value, attitude, techniques or skills. It involves planned activities on the part of an organization to increase job knowledge and skills or modify the attitudes and social behavior of its members in the ways that are consistent with the goals of the organization and the requirements of the job. Training in Librarianship can be regarded as an organized training process for personnel of the library to learn useful skills (Ekere and Ugwu 2011). According to Tyokase (2014), librarians as managers are to be developed in all areas of managing the library to avoid being outdated. In the academic libraries, training refers to the various methods used in getting new or present employees, the skills or the knowledge they need to perform their job. One of the major reasons advanced in favor of the off-the-job training is based on the premise that trainees require a certain amount of vocational or technical knowledge before entering the organization or office being assigned a specific task.

According to Abban (2018), it is correct to assert that training is necessary for libraries as well as in other organizations. This is because the benefits that are accrued from training by both the staff and the organization cannot be attained without training. No matter how well educated a librarian or any other library staff maybe, he or she may be lacking in one way or the other which he or she may need the training to enable him or her to be more efficient in the discharge of his or her responsibilities. Training is no doubt a good approach to improving staff performance in libraries (Bamgbose and Ladipo, 2017). However, training does not just occur. Certain 
strategies have to be evolved for effective training. According to Tyokase (2014) library, users heavily depend on the capability of the library staff to achieve their aims of going to the library. The efficiency of library staff means a lot to the library users as well as the library as an organization if they undergo training and retraining.

Tumba and Temboge (2018) posited that no matter how computerized an organization or a library maybe, high productivity depends on the level of motivation and the effectiveness of the workforce. Staff training, therefore, is an indispensable strategy for motivating workers. According to Udofia and Ikpe (2012) administration of the in-service training programme significantly influences teachers' attitudes to work in private secondary schools in Cross River State. In a similar development, Truitt (2011) study's found a direct relationship between one's positive training experiences and attitudes and one's proficiency. In his study, " $86.8 \%$ of those who had updated training had the most positive attitudes toward training $(\gamma=0.293, p<0.05)$. Furthermore, $80 \%$ of those who had negative training attitudes also had negative views on their proficiency $(\gamma=$ $0.465, p<0.000)$." The library organization, therefore, must have good training programs. This will give the librarians or information professional's opportunities for self-improvement and development to meet the challenges and requirements of new equipment and new techniques for performing their tasks (Hossain et al., 2019).

\section{Salary payment and job performance of university library personnel}

Pay refers to the amount of financial compensation that an individual receives as well as the extent to which such compensation is perceived to be equitable. The findings of Sajuyigbe et al. (2013) agreed that financial rewards have a significant impact on job satisfaction and performance. Ajie and Omotunde (2015) also found that there is a positive relationship between pay and performance. It was further concluded that salary payment plays vital role in human capital intensive firms to attract and retain the expert workforce. This entail that the greater financial reward, the lesser the anxiety of the employees regarding their financial state, thereby enhancing the impact in their self-esteem to the organization.

According to Tetteh et al. (2017) employees seek pay systems that might be perceived as simple, unambiguous, and in line with their expectations. It is likewise vital to make sure that the prevailing pay in libraries or other information establishments is considered in determining the pay structure in their organization. According to Daship (2012) good salary packages, adequate allowances, and bonuses are identified as strategies for improving the job performance of university library personnel in Nigeria. On the effects of motivation on staff productivity/performance at the Francis Suleiman Idachaba Library, University of Agriculture Makurdi carried out their study to examine the impact of motivation on staff performance and productivity in the University Library. The target population was 86 para-professional staff. The sample of 86 respondents was determined using the census method. A structured questionnaire and interview tools were administered on the 86 respondents from where 72 copies were retrieved. The study used simple percentages and frequency distribution tables to analyze data. The result revealed both the factors and the degree of impact in the following descending order: participation in decision making, job security challenging work assignment, monetary reward, and job incentives. It was obtrusive that their productivity changed into at its lowest ebb as further inquiry discovered that other than the mass retrenchment of team of workers in 2004, most effective three (4.2\%) of the staff were subsidized for schooling among 2004-2011.

\section{METHODOLOGY}

The survey research design method was adopted for the study and a self-structured questionnaire was used for data collection. The population of 223 library personnel was used as a census study to retrieved 
data. In the respondents' university libraries, the researchers administered the questionnaires on the face to face bases with the guidance of a research assistant that helped to identify the library personnel.

The data collected was analyzed using descriptive statistics precisely mean and standard deviations to answer the research questions while inferential statistics of one-way ANOVA was used to test the null hypotheses at 0.5 level of significance.

\section{RESULT}

Effect of Training on the Job Performance - The result in Table 1 reveals that item one has a mean of 3.93 and SD of 0.30 , item two has a mean of 3.83 and SD of .38, item three has a mean of 3.44 and SD of 0.89 , item four has a mean of 3.47 and SD of 0.85 , item five has a mean of 3.79 and SD of 0.41 , item six has a mean of 3.70 and SD of 0.46 , and item seven has a mean of 3.39 and SD of 0.97 .

Table 1: Perceived mean ratings of the effect of training on the job performance of university library personnel.

\begin{tabular}{|c|c|c|c|c|c|c|c|c|}
\hline $\mathbf{S} / \mathbf{N}$ & Item Descriptions & SA & $\mathbf{A}$ & D & SD & $\mathbf{N}$ & Mean & SD \\
\hline 1 & $\begin{array}{l}\text { On the job training encourages university library } \\
\text { personnel's job performance. }\end{array}$ & 210 & 12 & 0 & 1 & 223 & 3.93 & 0.30 \\
\hline 2 & $\begin{array}{l}\text { Training university library personnel in information } \\
\text { and communication technologies stimulate effective } \\
\text { delivery of automated library services. }\end{array}$ & 184 & 39 & 0 & 0 & 223 & 3.83 & 0.38 \\
\hline 3 & $\begin{array}{l}\text { Attending workshops, seminars and conferences } \\
\text { improve university library personnel's ability in } \\
\text { reference interview and communication skills for } \\
\text { effective service delivery }\end{array}$ & 144 & 46 & 19 & 14 & 223 & 3.44 & 0.89 \\
\hline 4 & $\begin{array}{l}\text { Training university library personnel on current } \\
\text { issues such as on-line cataloguing improve the } \\
\text { quality of service delivery. }\end{array}$ & 145 & 50 & 16 & 12 & 223 & 3.47 & 0.85 \\
\hline 5 & $\begin{array}{l}\text { Attending conferences, workshops and seminars } \\
\text { help up-date knowledge and skills of university } \\
\text { library personnel for effective job performance. }\end{array}$ & 176 & 47 & 0 & 0 & 223 & 3.79 & 0.41 \\
\hline 6 & $\begin{array}{l}\text { Training university library personnel result into } \\
\text { high productivity. }\end{array}$ & 157 & 66 & 0 & 0 & 223 & 3.70 & 0.46 \\
\hline \multirow[t]{2}{*}{7} & $\begin{array}{l}\text { Training university library personnel boost their } \\
\text { self-confidence in carrying out given task } \\
\text { effectively. }\end{array}$ & 145 & 37 & 23 & 18 & 223 & 3.39 & 0.97 \\
\hline & Grand mean & & & & & 223 & 3.65 & 0.38 \\
\hline
\end{tabular}

With a Grand mean of 3.65 and SD of 0.38 , this indicated that the respondents strongly agreed that training have effect on job performance of library personnel of universities in Benue State.

\section{Effects of salary payment on the job performance}

- The result in Table 2 reveals that item eight has a mean of 3.37 and SD of 0.95 , item nine has a mean of
3.45 and SD of 0.90 , item ten has a mean of 2.33 and SD of 1.25 , item eleven has a mean of 3.27 and SD of 0.97 , item twelve has a mean of 3.21 and SD of 0.93 and item thirteen has a mean of 2.27 and SD of 1.17. With a Grand mean of 2.98 and SD of 0.62 , this indicated that the respondents agreed that salary payment has effect on job performance of library personnel of universities in Benue State. 
Table 2: Perceived mean ratings of the effects of salary payment on the job performance.

\begin{tabular}{|c|l|c|c|c|c|c|c|c|}
\hline S/N & \multicolumn{1}{|c|}{ Item Descriptions } & SA & A & D & SD & N & Mean & SD \\
\hline $\mathbf{8}$ & $\begin{array}{l}\text { Prompt payment of salary arouses the } \\
\text { interest of university library personnel } \\
\text { to finish a given office task on time. }\end{array}$ & 141 & 38 & 29 & 15 & 223 & 3.37 & 0.95 \\
\hline $\mathbf{9}$ & $\begin{array}{l}\text { University library personnel are more } \\
\text { committed to duties when salaries are } \\
\text { promptly paid. }\end{array}$ & 155 & 23 & 36 & 9 & 223 & 3.45 & 0.90 \\
\hline $\mathbf{1 0}$ & $\begin{array}{l}\text { Prompt payments of salaries spur } \\
\text { university library personnel's interest } \\
\text { to work extra time. }\end{array}$ & 65 & 28 & 45 & 85 & 223 & 2.33 & 1.25 \\
\hline $\mathbf{1 1}$ & $\begin{array}{l}\text { Delay in salary payment of university } \\
\text { library personnel hinders their } \\
\text { commitment. }\end{array}$ & 123 & 59 & 20 & 21 & 223 & 3.27 & 0.97 \\
\hline $\mathbf{1 2}$ & $\begin{array}{l}\text { Industrial strike actions due to non- } \\
\text { payment of university library } \\
\text { personnel's salaries deter their job } \\
\text { performance. }\end{array}$ & 111 & 60 & 39 & 13 & 223 & 3.21 & 0.93 \\
\hline $\mathbf{1 3}$ & $\begin{array}{l}\text { Prompt payment of salaries reduces the } \\
\text { level of truancy among university } \\
\text { library personnel. }\end{array}$ & 59 & 12 & 82 & 70 & 223 & 2.27 & 1.17 \\
\hline Grand Mean & & & & & $\mathbf{2 2 3}$ & $\mathbf{2 . 9 8}$ & $\mathbf{0 . 6 2}$ \\
\hline
\end{tabular}

Table 3a: Statistics of university library effects of training.

\begin{tabular}{|c|c|c|c|c|}
\hline Institution & N & Mean & Std. Deviation & Std. Error \\
\hline BSU & 78 & 3.80 & 0.31 & 0.04 \\
\hline UAM & 121 & 3.63 & 0.37 & 0.03 \\
\hline Uni. Mkar & 24 & 3.26 & 0.36 & 0.07 \\
\hline
\end{tabular}

Table 3b: ANOVA for Effect of training on job performance.

\begin{tabular}{|l|c|c|c|c|c|}
\hline & Sum of Squares & df & Mean Square & F & Sig. \\
\hline Between Groups & 5.34 & 2 & 2.67 & 21.71 & 0.00 \\
\hline Within Groups & 27.06 & 220 & 0.12 & & \\
\hline Total & $\mathbf{3 2 . 4 0}$ & $\mathbf{2 2 2}$ & & & \\
\hline
\end{tabular}

Table 4a: Statistics of university library salary payment on the job performance.

\begin{tabular}{|c|c|c|c|c|}
\hline Institution & $\mathrm{N}$ & Mean & Std. Deviation & itd. Error \\
\hline BSU & 78 & 3.30 & 0.50 & 0.06 \\
\hline UAM & 121 & 2.90 & 0.60 & 0.05 \\
\hline Uni. Mkar & 24 & 2.34 & 0.39 & 0.08 \\
\hline
\end{tabular}


Test of research hypotheses - The formulated hypotheses for the study were tested at the 0.5 level of significance.

Hypothesis one - There is no significant difference between the mean ratings of responses of library personnel on perceived effects of training on the job performance of library personnel of universities in Benue State. The result of this hypothesis is presented in Table 3a, and $3 b$.

From Table 3a above, it can be seen that the statistics for perceived effect of training on job performance was variously presented. From Benue State University, it was found that 78 library respondents had perceived mean effect on the job training to be 3.80 with standard deviation of $0.31,121$ library respondents from UAM have mean rating of 3.63 with standard deviation of 0.37 while that of 24 respondents from University of Mkar had 3.26 with standard deviation of 0.36 . Check for the noted difference, as the results were not identical, ANOVA is used to ascertain whether the noted differences are significant. The ANOVA is presented in Table $\mathbf{3 b}$. From Table 3b, it can be seen that the ANOVA results gave: $\mathrm{F}=21.71, \mathrm{df}=2$ and sig. $=0.00=$ p. Since $\mathrm{p}$ is less than 0.05 the difference noted is significant. So the hypothesis which stated that there is no significant difference between the mean ratings of responses of library personnel on perceived effects of training on the job performance of library personnel of universities in Benue State is rejected.
Hypothesis two - There is no significant difference between the mean ratings of responses of library personnel on perceived effects of salary payment on the job performance of library personnel of universities in Benue State. The result of this hypothesis is presented in Table $4 \mathbf{a}$, and $\mathbf{4 b}$. From Table $4 \mathbf{a}$ above, it can be seen that the statistics for perceived effect of salary paymenton job performance was variously presented.

From Benue State University, it was found that 78 library respondents had perceived mean effect on the salary paymentto be 3.30 with standard deviation of $0.50,121$ library respondents in UAM have mean rating of 2.90 with standard deviation of 0.60 while that of 24 respondents from University of Mkarhad 2.34 with standard deviation of 0.39 . Check for the noted difference, as the results were not identical, ANOVA is used to ascertain whether the noted differences are significant. The ANOVA is presented in Table $4 \mathbf{b}$ below.

From Table $4 \mathbf{b}$, it can be seen that the ANOVA results gave: $F=31.38, \mathrm{df}=2$ and sig. $=0.00=$. Since $\mathrm{p}$ is less than 0.05 the difference noted is significant. So the hypothesis which stated that there is no significant difference between the mean ratings of responses of library personnel on perceived effects of salary payment on the job performance of library personnel of universities in Benue State is rejected.

Table 4b: ANOVA for effect of salary payment on job performance of university library personnel

\begin{tabular}{|c|c|c|c|c|c|}
\hline & Sum of Squares & df & Mean Square & F & Sig. \\
\hline Between Groups & 18.69 & 2 & 9.34 & 31.38 & 0.00 \\
\hline Within Groups & 65.50 & 220 & 0.30 & & \\
\hline Total & $\mathbf{8 4 . 1 8}$ & $\mathbf{2 2 2}$ & & & \\
\hline
\end{tabular}

\section{DISCUSSION}

The finding of research question one revealed that there was a significant difference between the mean ratings of responses of library personnel at the University of Agriculture, Makurdi, Benue State
University and the University of Mkar on perceived effects of training on the job performance of library personnel of universities in Benue State. Although, respondents indicated that training has a positive effect on the job performance of university library 
personnel in Benue State, the perceived effect of training on the job performance of library personnel of universities is felt at a higher degree more than other universities in the State. This finding was in agreement with Udofia and Ikpe (2012), who found that the administration of the in-service training programme significantly influences teachers' attitudes to work in private secondary schools in Cross River State. Also, this study was in agreement with Tyokase (2014), who conducted a study on staff training in academic libraries as a motivational tool for maximum performance and found out that the staff of Taraba State University benefitted from various training programs such as conferences, workshops, seminars, orientations, job rotation, onthe-job training, and classroom lecture method but stressed that majority of the respondents needed to explore more in areas of computer literacy, cataloguing and classification to be effective on their job performance.

Furthermore, Tumba and Temboge (2018) posit that motivating factors like training opportunities have a significant relationship on job performance. Similarly, Truitt (2011) found that $86.8 \%$ of those who had updated training had the most positive attitudes toward work and $80 \%$ of those who had negative training attitudes had negative views on their proficiency. In addition, this work was similar to the study of Madukoma et al. (2014), who aptly stress that employee motivation is very important and vital in organizations and any job if people are to give their best. Also, Upev et al. (2015) carried out their study to examine the impact of motivation on staff performance and productivity in the university library and reported that only three $(4.2 \%)$ of the staff were sponsored for training from 2004-2011. This is so because library staffs that are trained have the needed knowledge and skills to do their work with zeal and ease (Ahamed et al., 2019). They are able to satisfy their clients' needs, as well as attract promotions because of their training (Parvez et al., 2019). Respondents, however, indicated that salary payment has a positive effect on the job performance of university library personnel in Benue State, the findings, therefore, imply that university library personnel had similar responses regarding the perceived effect of salary payment on the job performance of library personnel of universities in the State (Islam, 2019).

The perception differs significantly among the three universities. This finding was in agreement with Upev et al. (2015) which found among others that monetary reward and job incentives influence job productivity. Also, this finding was similar to Sajuyigbe et al. (2013) who discovered that pay was one of the most significant variables in explaining job performance and satisfaction. This finding was also in line with Ajie and Omotunde (2015) who found that there was a positive relationship between pay and job performance and further concluded that pay plays a vital role in human capital intensive firms to attract and retain the expert workforce.

The difference between the mean ratings of responses of library personnel on perceived effects of salary payment on the job performance of library personnel of universities in Benue State could be attributed to different salary structures/packages, allowances, bonuses as well as motivational strategy received from their various universities.

\section{CONCLUSION}

Based on the study findings, it is concluded that motivation had a positive effect on the job performance of library personnel of universities in Benue State. Hence, the indices of the motivation of training and salary payment had a significant difference on the job performance of library personnel in the three universities where the study was conducted. Based on the findings of the study, the following recommendations were made: Library personnel of universities in Benue State should constantly be sent on training and retraining such as workshops, seminars, conferences, and ICT training to improve on their work skills for effective job performance. The salaries of university library 
personnel should be promptly paid to enhance commitment to duty for higher job performance.

\section{ACKNOWLEDGEMENT}

We are grateful to the authority of Benue State University for their support in the successful research.

\section{CONFLICTS OF INTEREST}

The authors have no conflicts of interest to publish it.

\section{REFERENCES}

1. Abban, S. (2018). Training and development of library staff: A case of two university libraries in Ghana. Lib. Philosophy and Pract., 5(1), 1-26.

2. Ahamed A, Sikdar MM, and Shirin S. (2019). Bangladesh-East Asia relations in the context of Bangladesh's look east policy. Br. J. Arts Humanit., 1(4), 1-13. https://doi.org/10.34104/bjah.019.0113

3. Ajie, I. A., and Omotunde, O. I. (2015). Job satisfaction and organizational commitment among library personnel in selected libraries in Ogun State, Nigeria. Information and Knowledge Management, 5(10), 22-24.

4. Akor, P. U. (2010). Motivation as correlate to job performance of professional librarians in the university libraries in Makurdi, Benue State. Unizik Journal of Research in Library and Information Science. 2(1), 54-64.

5. Bamgbose, A. A., and Ladipo, S. O. (2017). Influence of motivation on academic library employees' performance and productivity in Lagos, Nigeria. Information Impact: $J$. of Information and Knowledge Manag., 8(2), 33-47. https://doi.org/10.4314/iijikm.v8i2.3

6. Chintallo, S., and Mahadeo, J. (2013). Effect of motivation on employees' work performance at Ireland Blyth Limited: Proceedings of 8th Annual London Business Research Conference Imperial College, London. ISBN: 978-1-922069-28-39.

7. Daship, N. (2012). Job satisfaction and job performance of library personnel of National Library of Nigeria. MLS dissertation. University of Nigeria, Nsukka.
8. Ekere, J. N., and Ugwu, C. I. (2011). Influence of age, gender and working experience on librarians' job satisfaction in university libraries in Nigeria. Information Impact: J. of Information and Knowledge Management, 2(1), 1-14.

9. Hossain MR, Khatun S, and Rashid MA. (2019). Present status of information and internet services in union council of Madhukhali upazila: a case study, Br. J. Arts Humanit., 1(6), 35-44. https://doi.org/10.34104/bjah.019.35044

10. Idiegbeyan-Ose, J., Aregbesola, A., and Eyiolorunshe, T. (2019). Relationship between motivation and job satisfaction of staff in private university libraries, Nigeria. Academy of Strategic Management Journal, 18(1), 1-13. https://doi.org/1939-6104-18-1-319

11. Iqbal, S. M. J., Nabi, A. A., and Anuar, M. A., (2013). Impact of training on expectation of employee and employer: A comparative study. Inform. Manag. and Business Review, 5, 601-607.

12. Islam MN. (2020). The impact of human rights violation concerning the status of women and children in Bangladesh: a critical review, $B r . J$. Arts Humanit., 2(1), 1-13. https://doi.org/10.34104/bjah.02001013

13. Katamba, A. S., and Abdulsalam, A. S., (2014). An assessment of the levels of job motivation and satisfaction as predictors of job performance of library personnel in Nigerian universities. $J$. of Balkan Libraries Union, 2(2), 26-33.

14. Kendra, C. (2018). The incentive theory of motivation: Are actions B a desire for rewards? www.verywellmind.com/the-incentive-theory-ofmotivation-2795382

15. Kibichii, K. E., Kiptum, K. G., and Chege, K., (2016). Effects of performance management process on employee productivity: a survey of commercial banks in Turkana County. IOSR J. of Business and Management, 18(11), 52-62. https://doi.org/10.9790/487X-1811045264

16. Mabaso, C. M., and Dlamini, B. I. (2017). Impact of compensation and benefits on job satisfaction. Research J. of Business Management, 1, 80-90. https://doi.org/10.3923/rjbm.2017.80.90 
17. Madukoma, E., Akpa, V. O., and Okafor, U. N. (2014). Effect of training and motivation on job performance of library personnel of university of Lagos, Nigeria. Open Access Library J., 1(8) 1-8. http://dx.doi.org/10.4236/oalib.1100804

18. Nyitse, D. S. (2016). The impact of manpower training and development on profit generation (A case study of Benue Breweries, Makurdi). B.Sc. project. Benue State University, Nigeria.

19. Parvez MS, Rahaman MA, Fatema K, and Mondal DR. (2019). Impact of social networking sites on the interpersonal relationship among teenager: a sociological analysis in the district of Bagerhat. Br. J. Arts Humanit., 1(5), 14-27. https://doi.org/10.34104/bjah.019.1427

20. Rafiei, N., and Davari, F., (2015). The role of human resources management on enhancing the teaching skills of faculty members. Materia socio-medica, 27(1), 35-38. https://doi.org/10.5455/msm.2014.27.35-38

21. Sajuyigbe, A. S, Olaoye, B. O., and Adeyemi, M. A. (2013). Impact of reward on employee's performance in selected manufacturing companies in Ibadan. International Journal of Arts and Commerce, 2(2), 44-69. https://pdfs.semanticscholar.org/9e04/f884bf4af6a8 4fb63762e57c2a6af547766c.pdf

22. Silva, F. A., and Borsato, M. (2017). Organizational performance and indicators: Trends and opportunities. Procedia Manufacturing, 11, 19251932.

https://doi.org/doi.org/10.1016/j.promfg.2017.07.33 $\underline{6}$

23. Tetteh, R., Mohammed, S., and Azumah, A. A. (2017). What is the effect of wages and super- vision on productivity? The perspective of Sunyani Technical University staff. Munich Personal RePEc Archive, 81473.

https://mpra.ub.uni-muenchen.de/81473/

24. Truitt, D. L. (2011). Effect of training and development on employee attitude as it relates to training and work proficiency. SAGE Open, 1-13. https://doi.org/10.1177/2158244011433338

25. Tumba, T., and Temboge, A., (2018). Staff development programmes and job satisfaction among library staff of higher institutions in Adamawa State, Nigeria. Information Impact: J. of Inform. and Knowledge Manag., 8(2), 58-67. https://doi.org/10.4314/iijikm.v9i2.5

26. Tyokase, T. (2014). Staff training in academic libraries as a motivational tool for maximum performance. A case study of Taraba State University Library, Jalingo. BLIS project. Benue State University, Makurdi.

27. Udofia, U. I., and Ikpe, U. N., (2012). Administration of in-service training and teachers' attitude to work in private secondary schools in Cross Rivers State of Nigeria. Inter. J. of Academic Research in Business and Social Sciences, 2(10), 94 -113. https://core.ac.uk/download/pdf/25716977.pdf

28. Upev, M. T., Chorun, M. T., and Idachaba, J. A. (2015). The effects of motivation on staff productivity/performance at the Francis Suleman Idachaba Library, University of Agriculture, Makurdi-Nigeria. IOSR J. of Research \& Method in Education, 5(2), 1-7.

http://www.iosrjournals.org/iosr-jrme/papers/ Vol5\%20Issue-2/Version-3/A05230107.pdf

Citation: Ubagu MM, and Gbuushi JA. (2020). Perceived effect of motivation on the job performance of library personnel of universities in Benue state, Nigeria, Br. J. Arts Humanit., 2(1), 14-23. https://doi.org/10.34104/bjah.020014023 (C) क्) 